\title{
KECERDASAN EMOSIONAL TOKOH TOTTO CHAN DALAM NOVEL MADOGIWA NO TOTTO CHAN KARYA TETSUKO KUROYANAGI MENURUT TEORI GOLEMAN Sebuah Analisis Psikologi
}

\author{
Noor Laili Faizah, Sri Oemiati \\ sri.oemiati@dsn.dinus.ac.id. \\ Universitas Dian Nuswantoro
}

\begin{abstract}
This research is a descriptive psychological analysis study according to Goleman's theory of the emotional intelligence of Totto Chan in the novel Madogiwa no Totto chan by Tetsuko Kuroyanagi. The purpose of this study was to determine the level of emotional intelligence of Totto Chan in the novel Madogiwa No Totto Chan by Tetsuko Kuroyanagi. The results of the analysis in this study indicate that the character of Totto Chan has seven elements of emotional intelligence. This is indicated by the confidence to succeed very high, always trying to find out and try new things, the main character plans well and does not despair to achieve goals when intending to do something, the main character has self-control in adjusting his desires to the demands of the environment, the main character has a very high relationship with other people where the main character is able to understand their situations and conditions, the main character communicates well, the main character can be cooperative with others. Therefore Totto Chan's emotional intelligence is high.
\end{abstract}

Keywords: emotional intelligence, Totto chan, cooperativeief.

Karya sastra sebagai hasil cipta manusia dapat memiliki nilai apabila dapat dinikmati dan memberikan manfaat bagi masyarakat pembaca atau penikmat karya sastra. Pada karya sastra, terdapat unsur keindahan yang menimbulkan rasa senang, terharu, menarik perhatian dan menyegarkan perasaan bagi penikmatnya. Seorang pengarang tidak hanya mengekspresikan pengalamannya saja tetapi juga mempengaruhi pembaca agar pembaca ikut memahami, menghayati dan menyadari berbagai masalah kehidupan masyarakat. Menurut Rene Wellek dalam Melani Budianta (1997:109) sastra adalah lembaga sosial yang memakai bahasa sebagai medium bahasa dalam menampilkan gambaran kehidupan, dan kehidupan itu sendiri adalah kenyataan sosial. 
Noor Laili Faizah, Sri Oemiati, Kecerdasan Emosional Tokoh Totto Chan dalam Novel Madogiwa no Totto Chan Karya Tetsuko Kuroyanagi Menurut Teori Goleman: Sebuah Analisis Psikologi

Pada umumnya sastra terbagi menjadi dua jenis yaitu karya sastra yang bersifat fiksi dan karya sastra yang bersifat nonfiksi. Karya sastra yang bersifat fiksi antara lain berupa novel, cerpen, roman, essei dan cerita rakyat. Sedangkan karya sastra nonfiksi meliputi puisi, drama dan sebagainya. Dalam Kamus Besar Bahasa Indonesia (KBBI) (2002 : 788) "Novel adalah karangan prosa yang panjang mengandung rangkaian cerita kehidupan seseorang dengan orangorang di sekelilingnya dengan menonjolkan watak dan sifat setiap pelaku". Hal ini berarti di dalam suatu novel biasanya bercerita kisah nyata tentang keadaan yang terjadi dalam masyarakat. Sehingga bersifat sosial karena mencerminkan masyarakat itu sendiri. Novel sebagai karya sastra fiksi harus menyajikan cerita yang menarik dan mempunyai tujuan yang indah. Oleh karena itu, novel dibentuk oleh unsur-unsur pembangun yang membentuk cerita yang kemudian membuat sebuah novel terwujud. Unsur-unsur pembangun yang membentuk sebuah novel terdiri dari unsur intrinsik dan unsur ekstrinsik. Unsur intrinsik adalah unsur-unsur yang membangun karya sastra itu sendiri atau unsurunsur yang secara langsung membangun cerita. Unsur intrinsik suatu karya sastra adalah tema, alur, penokohan, sudut pandang, latar, gaya bahasa, amanat. Sedangkan unsur ekstrinsik adalah unsur pembangun karya sastra yang berada di luar suatu karya sastra namun ikut mempengaruhi karya sastra tersebut. Unsur-unsur ekstrinsik tersebut adalah sosial, kebudayaan, psikologis, ekonomi, politik, agama dan lain-lain yang mempengaruhi pengarang dalam karya yang ditulisnya.

Novel Madogiwa no Totto chan adalah novel karya sastra Tetsuko Kuroyanagi yang menceritakan gadis kecil yang bernama Totto Chan. Sebagai seorang gadis cilik dengan segudang rasa ingin tahu, Totto-chan sering bertingkah laku aneh di sekolah. Mulai dari membuka tutup laci mejanya, hingga memanggil penyanyi jalanan, dan bahkan berdiri berjam-jam di depan jendela selama pelajaran berlangsung untuk berbicara pada burung wallet. Gurunya tidak tahan lagi dengan tingkah laku Tottochan dan akhirnya mengeluarkannya dari sekolah. Saat itu Totto-chan masih berada di kelas 1 sehingga ibunya yang bijak memutuskan untuk tidak memberi tahu Totto- 
chan kalau ia telah dikeluarkan dari sekolah. Sebaliknya, ibu Totto-chan menemukan sebuah sekolah yang sangat cocok dengan anaknya. Nama sekolah itu adalah Tomoe Gakuen. Sekolah unik tersebut dikepalai oleh Sosaku Kobayashi, dengan metode pengajaran yang jauh berbeda dengan sekolah konvensional saat itu. Kobayashi berani menembus sistem dan tradisi umum di masyarakat dengan menggunakan metode mendidik yang tidak lazim namun memberikan kesan dan pelajaran mendalam bagi anak muridnya.

Perilaku Totto chan yang dianggap "aneh dan nakal" di sekolah yang pertama membuat gurunya geram dan kehabisan akal. Totto chan berulang kali melakukan hal-hal yang tidak diinginkan selama pelajaran di kelas berlangsung. Baik di sekolah yang lama, di sekolah yang baru maupun di rumah, Totto-chan dikisahkan sebagai seorang anak yang sangat aktif, banyak bertanya dan bicara serta memiliki rasa ingin tahu yang besar. Hal tersebut membuat guru-guru di sekolahnya yang lama beranggapan bahwa Totto-chan adalah anak yang luar biasa nakal, sehingga ia dikeluarkan dari sekolah. Padahal Totto-chan hanyalah seorang murid kelas 1 SD dan ia tidak sampai satu tahun berada di sekolah itu. Hal tersebut menandakan bahwa perilaku Totto-chan sudah menjadi hambatan dalam fungsi akademisnya.

Namun, di Tomoe Gakuen dengan sistem belajar dan tenaga pengajar yang sangat mengerti kondisi Totto-chan, Totto-chan lebih banyak menunjukkan dampak positif. Ia selalu antusias dan semangat setiap kali dikenalkan mata pelajaran dan metode belajar yang baru.

Berdasarkan ringkasan novel di atas, metode pengajaran yang dilakukan oleh Sosaku Kobayashi memberikan banyak manfaat bukan hanya memberikan nilai kognitif dalam rapor saja melainkan dapat menjadi sarana pengembangan bagi muridmuridnya, karena setiap kegiatan yang dilakukan dalam proses belajar melibatkan daya pikir, emosi juga psikomotorik anak yang membuat mereka secara tidak langsung belajar tentang sains, biologi dan sejarah, mengaplikasikan ilmu di bawah bimbingan seorang ahli, mengenali rasa takut dan menaklukannya, bertanggung 
Noor Laili Faizah, Sri Oemiati, Kecerdasan Emosional Tokoh Totto Chan dalam Novel Madogiwa no Totto Chan Karya Tetsuko Kuroyanagi Menurut Teori Goleman: Sebuah Analisis Psikologi

jawab atas perbuatan, serta makna menghargai perbedaan. Yang terpenting dari semua itu adalah murid-muridnya menikmati proses belajar itu sendiri.

Untuk meneliti tingkat kecerdasan emosional tokoh utama dalam novel Madogiwa no Totto Chan ini, penulis menggunakan teori dari Daniel Goleman mengenai kecerdasan emosional.

\section{KAJIAN TEORETIS}

Karya sastra adalah karya seorang pengarang yang merupakan hasil perenungan dan imajinasi secara sadar dari hal-hal yang diketahui, dihindari, dirasa, ditanggapi dan difantasikan, disampaikan kepada khalayak melalui media bahasa dengan segala perangkatnya sehingga menjadi sebuah karya yang indah. Itulah sebabnya masalahmasalah yang terdapat di dalam karya sastra mempunyai kemiripan dengan yang ada di luar karya sastra.

Siswanto (1993:19) menyebutkan bahwa karya sastra merupakan cermin dari dunia nyata, baik dari dunia nyata yang sesungguhnya maupun cermin dari dunia nyata yang sudah bercampur dengan imajinasi dan perenungan pengarang. Sastra sebagai "gejala kejiwaan" di dalamnya terkandung fenomena-fenomena yang terkait dengan psikis atau kejiwaan. Dengan demikian, karya sastra dapat didekati dengan menggunakan pendekatan psikologi. Karya merupakan hasil ungkapan kejiwaan seorang pengarang yang berarti di dalamnya ternuansakan suasana rasa, karena dalam karya sastra tersebut di dalamnya terkandung fenomena-fenomena kejiwaan, yang tampak pada pelaku-pelaku cerita, maka sebuah karya sastra dapat didekati dengan menggunakan penerapan kaidah psikologi terhadap pelaku-pelaku karya sastra (Aminuddin 1990: 93).

Walgito (2004:1) menjelaskan bahwa ditinjau dari segi bahasa psikologi berasal dari kata psyche yang berarti jiwa dan logos berarti ilmu atau ilmu pengetahuan, 
karena itu psikologis sering diartikan dengan ilmu pengetahuan tentang jiwa. Psikologi merupakan ilmu yang mempelajari dan menyelidiki aktivitas dan tingkah laku manusia. Pendekatan psikologi pada karya sastra memusatkan perhatian pada tokoh-tokoh, dari tokoh-tokoh tersebut maka akan ditemukan adanya gejala-gejala yang tidak terlihat atau bahkan dengan sengaja disembunyikan pengarang dalam karya sastra tersebut.

Hubungan sastra dengan psikologi sangat dekat, karena sastra dengan psikologi mempunyai objek yang sama yaitu manusia dan kehidupannya. Hal ini tentu dapat kita terima, karena antara sastra dan psikologi memiliki hubungan lintas yang bersifat tak langsung dan fungsional (Darmanto Jatman dalam Aminuddin 1990:101).

Hubungan tak langsung yang dimaksudkan adalah baik sastra maupun psikologi memiliki tempat yang sama yaitu kejiwaan manusia secara mendalam. Pengarang dan psikolog adalah sama-sama manusia biasa. Pengarang dan psikolog menangkap kejiwaan manusia secara mendalam kemudian diungkapkan dalam bentuk karya sastra. Sedangkan hubungan fungsional antara sastra dan psikologi adalah keduanya sama-sama berguna untuk sarana mempelajari keadaan kejiwaan orang lain. Perbedaannya adalah dalam karya sastra gejala kejiwaan dari manusia-manusia imajiner sebagai tokoh dalam karya sastra, sedangkan dalam psikologi adalah gejala kejiwaan manusia-manusia riil (Suwardi 2004: 97).

\section{Kecerdasan}

Kecerdasan adalah anugerah istimewa yang dimiliki oleh manusia. Dengan kecerdasan manusia mampu memahami segala fenomena kehidupan secara mendalam. Menurut KBBI (2002 : 209), “cerdas” adalah sempurna perkembangan akal budinya (untuk berpikir, mengerti), tajam pikiran sedangkan "kecerdasan" adalah perihal cerdas, perbuatan mencerdaskan, kesempurnaan perkembangan akal budi seperti kepandaian, ketajaman pikiran. 
Noor Laili Faizah, Sri Oemiati, Kecerdasan Emosional Tokoh Totto Chan dalam Novel Madogiwa no Totto Chan Karya Tetsuko Kuroyanagi Menurut Teori Goleman: Sebuah Analisis Psikologi

Dalam makna harfiah Oxford English Dictionary mendefinisikan emosi sebagai setiap kegiatan atau pergolakan pikiran, perasaan, nafsu, setiap keadaan mental yang hebat atau meluap-luapnya. Sejumlah teoritikus mengelompokkan emosi dalam golongan-golongan besar, meskipun tidak semua sepakat tentang golongan itu.

Adapun emosi menurut penggolongannya (Goleman: 411) adalah sebagai berikut :

1) Amarah meliputi bingung, mengamuk, marah besar, jengkel, kecil hati, terganggu dan lain-lain

2) Kesedihan meliputi pedih, sedih, muram, suram, melankolis, putus asa dan lain-lain

3) Rasa takut seperti cemas, gugup, khawatir, waspada, fobia dan lain-lain

4) Kenikmatan misalnya bahagia, gembira, senang, bangga

5) Cinta meliputi penerimaan, persahabatan, kepercayaan, kebaikan hati, rasa dekat, bakti, hormat

6) Terkejut seperti terkesiap, takjub, terpana

7) Jengkel meliputi hina, jijik, muak, mual, benci, tidak suka dan lain-lain

8) Malu seperti rasa salah, malu hati, kesal hati, sesal, hina, aib dan hati hancur lebur.

Semua emosi pada dasarnya, adalah dorongan untuk bertindak, rencana seketika untuk mengatasi masalah yang telah ditanamkan secara berangsur-angsur. Akar kata emosi adalah movere, kata kerja Bahasa Latin yang berarti "menggerakkan, bergerak", ditambah awalan "e-" untuk memberi arti "bergerak menjauh", menyiratkan bahwa kecenderungan bertindak merupakan hal mutlak dalam emosi (Goleman : 7).

....kita memiliki dua pikiran, satu yang berpikir dan satu yang merasa. Kedua pikiran tersebut, yang emosional dan yang rasional, pada umumnya bekerja dalam keselarasan yang erat, saling melengkapi cara-cara mereka yang amat berbedadalam mencapai pemahaman guna mengarahkan kita menjalani 
kehidupan duniawi. Biasanya ada keseimbangan antara pikiran emosional dan pikiran rasional, emosi member masukan dan informasi kepada proses pikiran rasional dan pikiran rasional memperbaiki dan terkadang memveto masukan-masukan emosi tersebut. Namun, pikiran emosional dan rasional merupakan kemampuan-kemampuan yang semi mandiri, masing-masing, sebagaimana akan kita lihat, mencerminkan kerja jaringan sirkuit yang berbeda, namun saling terkait, di dalam otak. (Goleman : 12)

Hal ini berarti, "cerdas" menurut Goleman mengandung dua arti, pertama cerdas pikiran dan kedua cerdas emosional. Cerdas pikiran yang dimaksudkan adalah apabila seseorang melakukan suatu tindakan yang bersifat intelektual dimana unsur akal dan pikiran lebih mempengaruhi. Sedangkan cerdas emosional apabila seseorang tersebut menyikapi sesuatu dengan lebih dipengaruhi oleh unsur emosi dan perasaan. Emosi dan akal adalah dua bagian dari satu keseluruhan.

Kecerdasan emosi menggambarkan kecerdasan hati dan kecerdasan intelektual menggambarkan kecerdasan akal atau otak. Kecerdasan intelektual dan kecerdasan emosional adalah sumber daya sinergis, tanpa yang satu yang lain menjadi tidak sempurna. Konsep pendidikan formal cenderung melakukan penilaian tinggi terhadap kecerdasan intelektual sehingga membuat kecerdasan emosi menjadi berkurang dan menjadi pelengkap terhadap kecerdasan intelektual. Peringkat di sekolah, kemampuan untuk berbahasa asing merupakan contoh kecerdasan intelektual.

Goleman (2006: 44) menyatakan bahwa setinggi-tingginya kecerdasan intelektual menyumbang kira-kira $20 \%$ bagi faktor-faktor yang menentukan sukses individu dalam hidup sedangkan $80 \%$ dari kekuatan-kekuatan lain termasuk diantaranya kecerdasan emosional. Kecerdasan akademis praktis tidak menawarkan persiapan untuk menghadapi gejolak-atau kesempatan yang ditimbulkan oleh kesulitan-kesulitan hidup. Namun, bahkan IQ yang tinggi pun tidak menjamin kesejahteraaan, gengsi, atau kebahagiaan hidup; sekolah dan budaya kita lebih menitikberatkan pada kemampuan akademis, mengabaikan kecerdasan emosional, yaitu serangkaian ciri-ciri-sebagian ada yang menyebutnya karakter---yang juga sangat besar pengaruhnya terhadap nasib kita. 
Noor Laili Faizah, Sri Oemiati, Kecerdasan Emosional Tokoh Totto Chan dalam Novel Madogiwa no Totto Chan Karya Tetsuko Kuroyanagi Menurut Teori Goleman: Sebuah Analisis Psikologi

\section{Kecerdasan Emosi}

Bayi mempelajari banyak hal mengenai ibunya, seperti rasa sayang, rasa sedih, ataupun rasa gembira melalui sentuhan hangat dari ibu, ucapan ataupun nyanyian yang disenandungkan, serta hal lain yang disampaikan oleh ibunya melalui pesan emosi. Sang ibu juga mempelajari emosi anak melalui pesan emosi yang disampaikan anak melalui tangisannya, ekspresi sedih dan pesan emosi lainnya (Amaryllia 2009 : 19)

Semenjak bayi manusia sudah mampu menunjukkan emosi yang sedang dirasakannya dengan dibantu oleh reaksi fisiknya misalnya menangis atau tertawa dan perubahan pada raut muka yang mudah dikenali seperti takut atau kaget. Emosi, dalam hal ini merupakan satu-satunya cara untuk berkomunikasi dengan dunia luar sebelum anak tersebut memiliki kemampuan berbicara. Perkembangan emosi anak dimulai sejak mereka dilahirkan di dunia. Proses untuk melatih emosi dapat dilakukan oleh orangtua atau guru pada saat anak tersebut sudah memiliki kemampuan untuk berkomunikasi.

Goleman (2006:275) juga menyatakan kesempatan pertama untuk membentuk kecerdasan emosional pada tahap awal usia anak dan akan terbentuk sepanjang anak sekolah. Kemampuan emosional yang diperoleh anak di dalam kehidupan kelak akan bergantung pada kemampuan anak tersebut.

Pembelajaran emosi dimulai pada saat-saat paling awal kehidupan dan terus berlanjut sepanjang masa kanak-kanak. Semua pergaulan kecil antara orang tua dan anaknya mempunyai makna emosional tersembunyi, dan dalam pengulangan pesanpesan ini selama bertahun-tahun, anak-anak membentuk inti pandangan serta kemampuan emosionalnya. (Goleman : 276)

Kecerdasan emosi itu sendiri terdiri atas dua kata, yaitu kecerdasan dan emosi. Kecerdasan itu sendiri bermula pada pikiran yang ada pada manusia merupakan kombinasi antara kemampuan berpikir (kemampuan kognitif), kemampuan terhadap affection (kemampuan pengendalian secara emosi), dan 
unsur motivasi (atau conation). Pemahaman mengenai kecerdasan itu sendiri berkaitan dengan unsure kognitif yang berkaitan dengan daya ingat, reasoning (mencari unsur sebab akibat), judgement (proses pengambilan keputusan) dan pemahaman abstraksi. Pemahaman mengenai emosi itu sendiri berkaitan dengan perasaan hati (mood), pemahaman diri dan evaluasi serta kondisi perasaan lain seperti rasa bosan ataupun perasaan penuh dengan energy. (Amaryllia $2009: 8$ )

Salah satu definisi yang pertama kali dirumuskan oleh dua orang peneliti kecerdasan emosi yaitu Jack Mayer dan Peter Salovey tahun 1990 menyatakan bahwa pada dasarnya kecerdasan emosi dapat diartikan sebagai kemampuan seseorang untuk menyadari emosi dan perasaannya sendiri di samping mengerti apa yang sedang dirasakan oleh orang lain, memiliki kemampuan untuk mengendalikan emosinya serta menggunakan perasaannya dalam berpikir dan bertingkah laku.(Goleman : 64).

Setelah Mayer dan Salovey, penelitian tentang kecerdasan emosi masih terus berlanjut hingga saat ini dan yang paling sering digunakan bahan acuan dalam dunia pendidikan adalah model kecerdasan emosi yang diperkenalkan oleh Daniel Goleman. "Kecerdasan Emosional adalah kemampuan seperti kemampuan untuk memotivasi diri sendiri dan bertahan menghadapi frustasi, mengendalikan dorongan hati dan tidak melebih-lebihkan kesenangan, mengatur suasana hati dan menjaga agar beban stres tidak melumpuhkan kemampuan berpikir, berempati dan berdoa" (Goleman : 45).

Bagaimana tingkat emosi kita menghambat atau mempertinggi kemampuan kita untuk berpikir dan merencana, untuk mengejar latihan-latihan demi sasaran jangka panjang, untuk menyelesaikan permasalahan dan semacamnya, emosi-emosi itulah yang menentukan batas kemampuan kita untuk memanfaatkan kemampuan mental bawaan, dan dengan demikian menentukan keberhasilan kita dalam kehidupan. Dan, bagaimana kita termotivasi oleh perasaan antusiasme dan kepuasan pada apa yang kita kerjakan-atau bahkan oleh kadar optimal kecemasan-emosi-emosi itulah mendorong kita untuk berprestasi.dalam artian inilah kecerdasan emosional merupakan kecakapan yang secara mendalam mempengaruhi semua kemampuan lainnya, baik memperlancar maupun menghambat kemampuankemampuan itu. (Goleman: 112) 
Noor Laili Faizah, Sri Oemiati, Kecerdasan Emosional Tokoh Totto Chan dalam Novel Madogiwa no Totto Chan Karya Tetsuko Kuroyanagi Menurut Teori Goleman: Sebuah Analisis Psikologi

\section{Unsur Kecerdasan Emosi}

Goleman mengatakan bahwa kecerdasan emosi bukan berarti memberikan kebebasan kepada perasaan untuk berkuasa melainkan mengelola perasaan sedemikian rupa sehingga terekspresikan secara tepat dan efektif. Goleman juga menyebutkan bahwa pembentukan kecerdasan emosi adalah perkembangan dari lima wilayah utama yang dimiliki manusia yaitu mengenali emosi sendiri (kesadaran diri), mengelola emosi, memotivasi diri sendiri, mengenali emosi orang lain, dan membina hubungan (Goleman : 57).

\section{Kesadaran diri}

Kesadaran diri---mengenali perasaan sewaktu perasaan itu terjadimerupakan dasar kecerdasan emosional. Kemampuan untuk memantau perasaan dari waktu ke waktu merupakan hal penting bagi wawasan psikologi dan pemahaman diri. Ketidakmampuan untuk mencermati perasaan kita yang sesungguhnya membuat kita berada dalam kekuasaan perasaan. Orang yang memiliki keyakinan yang lebih tentang perasaannya adalah pilot yang andal bagi mereka, karena mempunyai kepekaan lebih tinggi akan perasaan mereka atas pengambilan keputusan-keputusan masalah pribadi, mulai dari masalah siapa yang akan dinikahi sampai ke pekerjaan apa yang akan diambil (Goleman: 58).

Mengenali emosi diri (kesadaran diri) adalah mengetahui apa yang dirasakan pada suatu kondisi tertentu dan mengambil keputusan dengan pertimbangan yang matang, serta memili tolak ukur yang realistis atas kemampuan diri dan kepercayaan yang kuat. (Esthi 2008: 80). Kesadaran diri adalah waspada baik terhadap suasana hati maupun pikiran kita tentang suasana hati. Orang-orang yang peka akan suasana hati mereka akan mandiri dan yakin akan batas-batas yang akan mereka bangun, kesehatan jiwanya bagus, dan cenderung berpendapat positif dalam kehidupan. Bila suasana hatinya sedang jelek, mereka tidak risau dan larut ke dalamnya dan mereka 
mampu melepaskan diri dari suasana itu dengan lebih cepat (Mayer dalam Goleman: $65)$.

\section{Pengendalian Diri}

Mengelola emosi merupakan kemampuan individu dalam menangani emosinya dengan baik sehingga berdampak positif dalam melaksanakan tugas, peka terhadap kata hati sehingga dapat mencapai tujuannya. (Esthi 2008: 70). Kemampuan ini mencakup kemampuan untuk menghibur diri sendiri, melepaskan kecemasan, kemurungan atau ketersinggungan dan akibat-akibat yang ditimbulkannya.

Orang-orang yang kemampuannya buruk dalam mngelola emosi akan terusmenerus bertarung melawan perasaan murung,sementara mereka yang pintar dapat bangkit kembali dengan jauh lebih cepat dari kemerosotan dalam kehidupan (Goleman: 58).

\section{Motivasi diri}

Motivasi merupakan dorongan untuk melakukan sesuatu sehingga menuntun seseorang untuk menuju sasaran, dan membantu dalam mengambil inisiatif, dan bertindak secara efektif untuk bertahan mengahadapi kegagalan dan frustasi (Esthi $2008: 70)$.

Untuk mendapatkan prestasi yang terbaik dalam kehidupan, kita harus memiliki motivasi dalam diri kita, yang berarti memilki ketekunan untuk menahan diri terhadap kepuasan dan mengendalikan dorongan hati serta mempunyai perasaan motivasi yang positif yaitu antusianisme, gairah, optimis dan keyakinan diri.

Orang yang pandai dalam memotivasi diri, mereka cenderung jauh lebih produktif dan efektif dalam hal apapun yang mereka kerjakan (Goleman: 58). 
Noor Laili Faizah, Sri Oemiati, Kecerdasan Emosional Tokoh Totto Chan dalam Novel Madogiwa no Totto Chan Karya Tetsuko Kuroyanagi Menurut Teori Goleman: Sebuah Analisis Psikologi

\section{Mengenali Emosi Orang Lain}

Kemampuan untuk mengenali emosi orang lain disebut juga empati. Empati atau kecakapan sosial adalah kemampuan dapat merasakan apa yang dirasakan orang lain, mampu memahami perspektif, mereka menyelaraskan diri dengan bermacammacam orang (Esthi hal. 70).

Menurut Goleman empati merupakan kemampuan seseorang untuk mengenali orang lain atau peduli, menunjukkan kemampuan empati seseorang. Individu yang memiliki kemampuan empati lebih mampu menangkap sinyalsinyal sosial yang tersembunyi yang mengisyaratkan apa-apa yang dibutuhkan orang lain (Goleman: 59).

\section{Membina Hubungan}

Kemampuan dalam membina hubungan merupakan suatu ketrampilan yang dapat menangani emosi dengan baik ketika berhubungan dengan orang lain dan dengan cermat membaca situasi dan jaringan sosial, berinteraksi dengan menggunakan ketrampilan untuk mempengaruhi serta menyelesaikan permasalahan dengan cermat.

Orang-orang yang hebat dalam ketrampilan membina hubungan ini akan sukses dalam bidang apapun yang mengandalkan pergaulan yang mulus dengan orang lain, mereka adalah bintang-bintang pergaulan (Goleman: 59).

Goleman juga menjelaskan bahwa seorang anak dapat dinyatakan siap untuk mulai masuk sekolah apabila anak sudah memiliki pengetahuan dasar yaitu "bagaimana caranya belajar". Pengetahuan ini dapat diperoleh dengan mengenali 7 unsur kecerdasan emosional, yaitu :

\section{a) Keyakinan}


Perasaan kendali dan penguasaan seseorang terhadap tubuh, perilaku, dan dunia, perasaan anak bahwa ia lebih cenderung berhasil daripada tidak dalam apa yang dikerjakannya, dan bahwa orang-orang dewasa akan bersedia menolong (Goleman: 274).

Memiliki kecerdasan emosional berarti memiliki kepercayaan pada diri sendiri dan selalu berpikir positif dalam mengerjakan sesuatu. Anak merasa bahwa ia akan berhasil menyelesaikan hal-hal yang sedang dikerjakan. Anak tersebut juga percaya bahwa ia dapat meminta pertolongan dari orang dewasa di sekitarnya apabila memang diperlukan. Contoh: Ketika sang ayah membesarkan anaknyaa untuk menjadi dokter atau pengacara, seorang david Schimmer (artis pendukung serial TV Friends) memilih untuk menjadi artis. Tentu saja orang tua kecewa dengan pilihan anaknya tersebut.

Namun, melihat keyakinan anaknya yang kuat dalam menempuh karier, akhirnya mereka mendukung keputusan anaknya. Dukunganmaupunadanya proses emosi untuk menerima keputusan anak membuat seorang anak sadar akan keputusannya, dan mengembangkan kualitas dirinya. Itulah yang dilakukan oleh David Schwimmer sehingga ia mampu melawan rasa rendah dirinya, dan berjuang dari titik nol untuk mencapai keberhasilan maupun karier yang selama ini dimiliki.

\section{b) Rasa ingin tahu}

Merupakan perasaan bahwa menyelidiki segala sesuatu itu bersifat positif dan menyenangkan (Goleman: 274).

Anak yang cerdas emosinya suka mencari tahu tentang hal-hal baru dan pengertian-pengertian baru. Anak beranggapan bahwa semua kegiatan untuk menyelidiki sesuatu itu bersifat positif dan menyenangkan. Contoh: Saat kita membawa sebuah mainan, kemudian memperlihatkan kepada seorang bayi. Seorang bayi memiliki rasa ingin tahu yang besar, ia akan mengambil, memasukkannya ke mulut, menjatuhkannya sambil mengamati apakah kita akan mengambilkan mainan 
Noor Laili Faizah, Sri Oemiati, Kecerdasan Emosional Tokoh Totto Chan dalam Novel Madogiwa no Totto Chan Karya Tetsuko Kuroyanagi Menurut Teori Goleman: Sebuah Analisis Psikologi

itu untuknya. Kemudian ia akan memandang ke arah kita dengan pandangan mata bersinar-sinar penuh harap seolah-olah mengatakan "Aku pintar, kan"

\section{c) Niat}

Hasrat dan kemampuan untuk berhasil, dan untuk bertindak berdasarkan niat itu dengan tekun. Ini berkaitan dengan perasaan terampil, perasaan efektif (Goleman : 274).

Memiliki kemampuan tinggi untuk dapat berhasil juga merupakan salah satu ciri anak yang cerdas emosinya. Anak selalu berusaha melakukan tugasnya dengan tekun dan memiliki keteguhan untuk mencapai keinginannya. Contoh: Ketika akan mengikuti ujian, seorang anak akan berniat untuk belajar supaya mendapatkan hasil yang maksimal.

\section{d) Kendali diri}

Kemampuan untuk menyesuaikan dan mengendalikan tindakan dengan pola yang sesuai dengan usia, suatu rasa kendali batiniah (Goleman: 274).

Kecerdasan emosi selalu didukung oleh kemampuan untuk beradaptasi dan menyesuaikan diri dengan lingkungannya. Anak yang mudah menyesuaikan diri dengan anak-anak lain ataupun orang dewasa di sekitarnya cenderung mampu mengendalikan perilakunya sesuai dengan harapan lingkungan terhadapnya. Contoh: Seorang anak usia empat tahun diberi tantangan untuk menunggu seseorang rampung menyelesaikan tugasnya, jika dapat menunggu akan diberi sebungkus permen dan akan memperoleh saat itu juga. Agar berhasil melewati godaan, anak tersebut menutup mata seshingga tidak melihat sebungkus permen yang dijadikan imingiming. Anak yang gigih akan mendapat imbalan dua bungkus permen. Sedangkan 
yanglebih menurutkan pada dorongan hati akan menyambar permen tersebut setelah orang itu meninggalkan ruangan untuk "bertugas".

\section{e) Keterkaitan}

Kemampuan untuk melibatkan diri dengan orang lain berdasarkan pada perasaan saling memahami (Goleman : 274).

Mampu memahami anak lain atau orang dewasa. Apabila seorang anak dapat memahami emosi yang dirasakan oleh orang lain akan timbul keterkaitan antara keduanya. Dengan demikian akan terjadi keterlibatan antara anak yang satu dengan anak yang lain. Contoh: Saat jam istirahat di sebuah TK, serombongan anak laki-laki berlari melintasi lapangan bermain. Reggie tersandung, lututnya terluka dan ia mulai menangis, tetapi anak-anak lain terus berlari, kecuali Roger, yang berhenti. Ketika isak tangis Reggie mereda, Roger menjatuhkan diri ke tanah dan menggosok-gosok lututnya sendiri, sambil berteriak "Lututku juga sakit!”.

\section{f) Kecakapan berkomunikasi}

Keyakinan dan kemampuan verbal untuk bertukar gagasan, perasaan, dan konsep dengan orang lain. Ini ada kaitannya dengan rasa percaya pada orang lain dan kenikmatan terlibat dengan orang lain, termasuk orang dewasa (Goleman : 274).

Memiliki kepercayaan kepada orang lain diawali dari kepercayaan terhadap diri sendiri yang merupakan unsur kecerdasan emosi. Anak yang dapat mempercayai orang lain, menikmati kegiatan bersosialisasi dengan anak-anak lain dan orang dewasa, dalam hal ini kemampuan berbicara akan membantunya berkomunikasi dengan orang lain melaui tukar pikiran atau pendapat dan mengutarakan keinginan. Contoh: Seorang anak yang ingin masuk dalam suatu kelompok permainan. Anak teresebut mengamati terlebih dahulu, kemudian menirukan apa yang sedang dilakukan anak lain dan pada akhirnya mengobrol dengan anak-anak itu dan sepenuhnya bergabung dalam kegiatan tersebut. 
Noor Laili Faizah, Sri Oemiati, Kecerdasan Emosional Tokoh Totto Chan dalam Novel Madogiwa no Totto Chan Karya Tetsuko Kuroyanagi Menurut Teori Goleman: Sebuah Analisis Psikologi

\section{g) Kerjasama}

Kemampuan untuk menyeimbangkan kebutuhannya sendiri dengan kebutuhan orang lain dalam kegiatan berkelompok (Goleman: 274).

Anak yang kecerdasan emosinya tinggi akan mampu melakukan sesuatu bersama-sama dengan anak lain. Dapat dikatakan bahwa anak yang siap belajar mampu menjaga keseimbangan antara kebutuhannya sendiri dengan kebutuhan anakanak lain dalam melakukan kegiatan berkelompok. Contoh: Guru membagi anak dalam kelompok dan menugaskan anak untuk menyisihkan sebagian uang jajan dalam satu minggu kemudian dikumpulkan. Secara berkelompok anak menyedekahkan uangnya kepada anak-anak miskin dan anak jalanan.

\section{METODE PENELITIAN}

Penelitian ini menggunakan metode deskriptif kualitatif. Data-data penelitian yang berupa kutipan-kutipan kalimat yang berkaitan dengan permasalahan penelitian ini dikaji dan dianalisi untuk menjelaskan sejauh mana kecerdasan emosional yang terkandung dalam novel “Madogiwa no Totto Chan ” karya Tetsuko Kuroyanagi.

\section{HASIL DAN PEMBAHASAN}

\section{Kecerdasan Emosional Totto Chan}

Analisis kecerdasan emosional tokoh utama dalam novel Madogiwa no Totto Chan berdasar teori goleman adalah sebagai berikut:

\section{Keyakinan}

Ketika bertemu dengan kepala sekolahnya yang baru, Totto chan di suruh menceritakan segala hal yang dia suka. Totto chan bercerita tentang segala hal hingga 
berjam-jam. Kepala sekolahnya yang baru mendengarkan tanpa rasa bosan, menguap ataupun lelah.

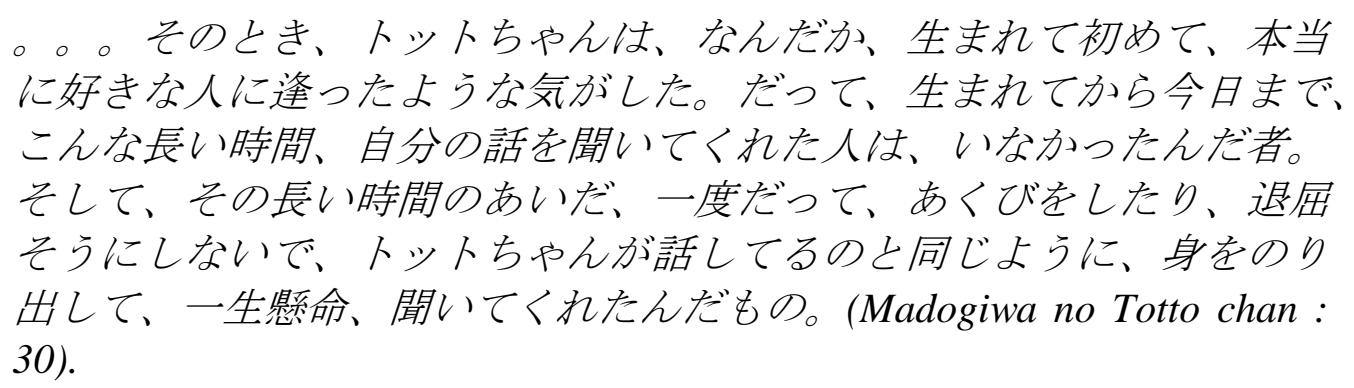

....sonotoki, Totto chan wa, nandaka, umarete hajimete, hontou ni sukina hito ni attayouna ki ga shita. Datte, umaretekara kyou made, konna nagai jikan, jibun no hanashi wo kiitekureta hito wa, inakattandamono. Soshite, sono nagai jikan no aida, ichidodatte, akubi wo shitari, taikutsu sounishinaide, totto chan ga hanashiteru no to onajiyouni, mi wo noridashite, isshoukenmei, kiite kuretandamono.

...Pada saat itu, Totto chan merasa telah bertemu dengan orang yang benarbenar disukainya. Tidak ada orang yang mau mendengarkan ceritanya sampai berjam-jam seperti itu. Dalam ceritanya yang panjang itu, dia tidak tampak bosan dan menguap serta selalu tertarik pada apa yang diceritakan Totto chan sama seperti Totto chan sendiri.

Pertemuan pertamanya dengan Totto chan begitu membekas di hati gadis cilik itu, ketika sang kepala sekolah tulus memberikan perhatian terhadap ceritanya selama berjam-jam. Belum pernah ada orang dewasa yang mau mendengarkan cerita dari anak seusia Totto chan selama berjam-jam. Kata "akubi wo shitari, taikutsu sounishinaide, totto chan ga hanashiteru no to onajiyouni, mi wo noridashite, isshoukenmei, kiite kuretandamono" menunjukkan perhatian yang tulus yang diberikan kepala sekolah kepada Totto chan.

Perhatian yang tulus berupa mendengarkan cerita tanpa bosan dan menguap serta selalu tertarik dengan cerita Totto chan yang diberikan kepala sekolahnya membuat Totto chan memiliki keyakinan pada diri sendiri untuk dapat bercerita tentang segala sesuatu selama berjam-jam. Kutipan di atas sesuai dengan Goleman mengenai unsur kecerdasan emosi yaitu keyakinan dimana keyakinan merupakan perasaan kendali dan penguasaan seseorang terhadap tubuh, perilaku, dan dunia, 
Noor Laili Faizah, Sri Oemiati, Kecerdasan Emosional Tokoh Totto Chan dalam Novel Madogiwa no Totto Chan Karya Tetsuko Kuroyanagi Menurut Teori Goleman: Sebuah Analisis Psikologi

perasaan anak bahwa ia lebih cenderung berhasil daripada tidak dalam apa yang dikerjakannya, dan bahwa orang-orang dewasa akan bersedia menolong.

\section{Rasa ingin tahu}

Saat itu Totto chan bersama ibunya turun dari kereta Oimachi di stasiun Jiyugaoka melewati pintu petugas pemeriksaan karcis. Totto chan melihat kotak penuh karcis petugas pemeriksa karcis.

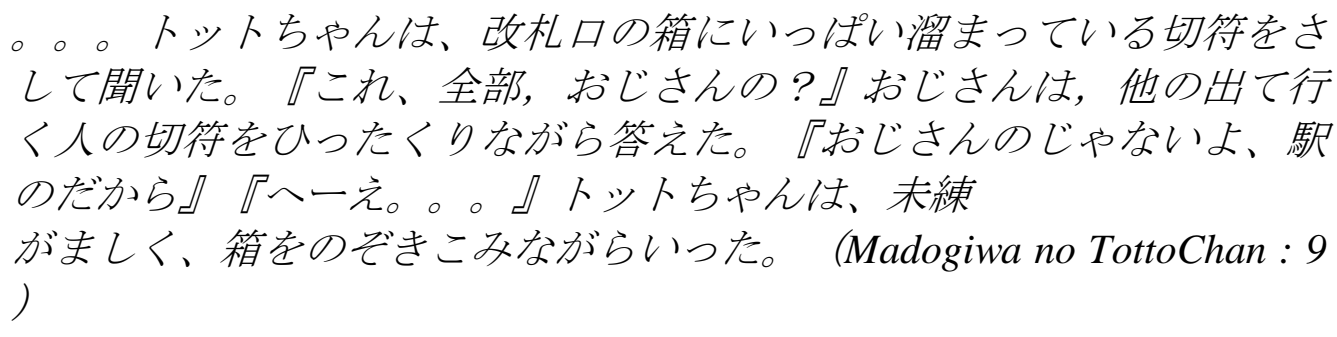
...Tooto chan wa, kaisatsuguchi no hako ni ippai tamatte iru kippu wo sashite kiita. "kore, zenbu, ojisanno?". Ojisan wa hoka no dete iku hito no kippu wo hittakurinagara kotaeta. "ojisannojanaiyo, eki no dakara" "hee..." Totto chan wa, miren ga mashiku, hako wo nozokikominagara itta.

...Totto chan bertanya dan menunjuk kotak yang penuh dengan karcis. "Itu semua punyamu?". "bukan, itu milik stasiun kereta," jawab petugas sambil mengambili karcis dari orang-orang yang keluar stasiun. "Oh". Totto chan memandang kotak itu dengan penuh minat.

Data "kore, zenbu, ojisanno?" menunjukkan rasa keingintahuan Totto chan. Dia ingin mengetahui apakah kotak yang penuh dengan karcis tersebut milik petugas pengumpul karcis. Kutipan di atas sesuai dengan Goleman mengenai unsur kecerdasan emosional yaitu rasa ingin tahu, dimana rasa ingin tahu merupakan perasaan bahwa menyelidiki segala sesuatu itu bersifat positif dan menimbulkan kesenangan.

Kutipan lain yang menunjukkan keingintahuan Totto chan adalah ketika kepala sekolah mengajak Totto chan melihat tempat murid-murid biasa makan siang. Kepala 
sekolah bertanya kepada murid-murid apakah mereka membawa sesuatu dari laut dan sesuatu dari pegunungan.

『海のものと、川のもの、って、なんだろう』トットちやんは、おか しくなった。でも、とっても、とっても、この学校は変わっていて、 面白そう。(Madogiwa no Totto chan: 33)

" umi no mono to, yama no mono, tte, nandarou?" totto chan wa, okashikunatta. Demo, tottemo, tottemo, kono gakkou wa kawatteite, omoshirosou.

"Apa maksudnya dengan sesuatu dari laut dan sesuatu dari pegunungan?" aneh sekali, pikirnya. Sekolah ini sangat sangat lain, tampak menyenangkan.

Ketika mendengar "umi no mono to, yama no mono, tte, nandarou?", Totto chan bertanya-tanya apa maksud perkataan kepala sekolah. Hal tersebut sesuai dengan Goleman berdasar unsur kecerdasan emosional yaitu rasa ingin tahu di mana rasa ingin tahu merupakan perasaan bahwa menyelidiki segala sesuatu itu bersifat positif dan menimbulkan kesenangan.

\section{Niat}

Totto-chan secara tidak sengaja pernah menjatuhkan dompetnya ke dalam bak penampungan kotoran di halaman belakang sekolah. Ia tidak menyerah atau bahkan merengek meminta tolong kepada orang yang lebih dewasa darinya untuk mengambil dompet tersebut melainkan ia berusaha mengambilnya sendiri walaupun sulit dan tempat penampungan itu sangat dalam, kotor, dan menjijikkan. Dengan semangat, Totto-chan mengeluarkan seluruh kotoran ke permukaan tanah dengan menggunakan gayung yang ia pinjam dari gudang tukang kebun hingga ia menemukan barang yang ia cari.

トットちゃんは、校長先生との約束どおり、山をくずして、完全に、 もとのトイレの池に、もどした。汲むときは、あんなに大変だったの に、もどすときは早かった。それから、水分のしみこんだ土も、ひし やくで削って、少し、もどした。地面を平らなして、 コンクリートの盍を、キチンと、もとの通りにして、ひしゃくも、物 置きに返した。(Madogiwa no Totto chan : 66) 
Noor Laili Faizah, Sri Oemiati, Kecerdasan Emosional Tokoh Totto Chan dalam

Novel Madogiwa no Totto Chan Karya Tetsuko Kuroyanagi Menurut Teori Goleman:

Sebuah Analisis Psikologi

Totto chan wa, kouchousensei to no yakusoku doori, yama wo kuzushite, kanzen ni, moto no toire no ike ni, modoshita. Kumutokiwa, annani taihen dattanoni, modosutokiwa hayakatta. Sorekara, suibun no shimi konda tsuchimo, hishakude kezutte, sukoshi, modoshita. Jimen wo tairanishite, konkuriito no futa wo, kichin to, moto no toorinishite, hishakumo, monookinikaeshita.

Totto chan memenuhi janjinya. Ia memasukkan semua kembali ke dalam bak penampungan. Mengeluarkan isi bak itu sungguh kerja yang keras, tapi memasukkannya kembali ternyata jauh lebih cepat. Tentu saja, Totto chan juga memasukkan tanah basah. Kemudian ia meratakan tanah, menutup kembali lubang itu dengan rapi, lalu mengembalikan gayung kayu yang dipinjamnya ke gudang tukang kebun.

Kutipan di atas menunjukkan bahwa Totto chan sudah berjanji dan berniat untuk mengembalikan seperti semula, maka ia tak kenal lelah untuk memasukkan kembali isi bak ke dalam lubangnya, kemudian memasukkan tanah yang basah, meratakan tanah, menutup kembali lubang itu dengan rapi seperti semula lalu mengembalikan gayung ke gudang tukang kebun. Hal tersebut sesuai unsur kecerdasan emosional yaitu niat, di mana niat adalah hasrat dan kemampuan untuk berhasil dan untuk bertindak berdasarkan niat itu dengan tekun. Ini berkaitan dengan perasaan terampil, perasaan efektif.

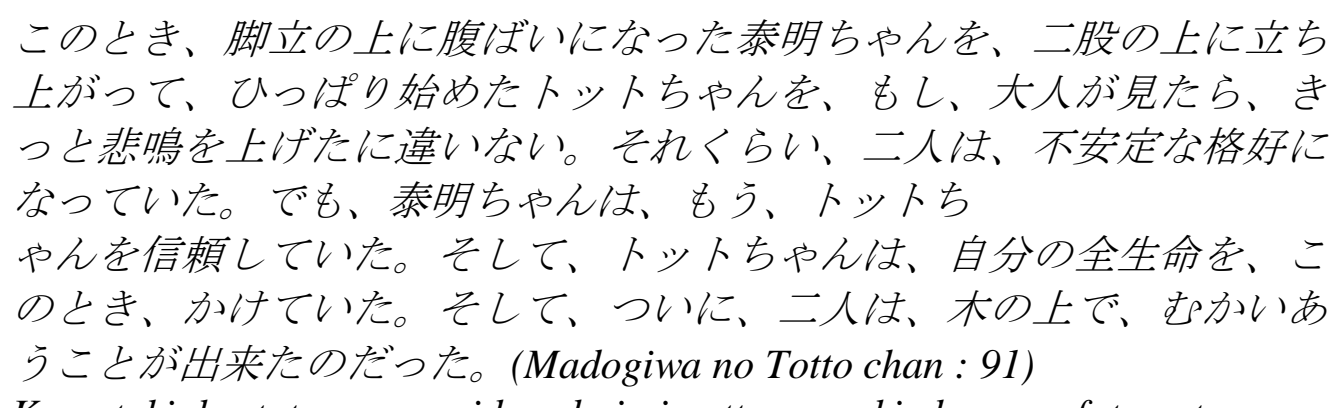

Kono toki, kyatatsu no ue ni harabai ni natta yasuaki chan wo, futamata no ue ni tachiagatte, hippari hajimeta Totto chan wo, moshi, otona ga mitara, kitto himei wo ageta ni chigainai. Sorekurai, futari wa, fuantei na kakkou natteita. Demo, Yasuaki chan wa, mou, totto chan wo shinraishiteita. Soshite, totto chan wa, jibun no zenseimei wo, konotoki, kaketeita. Soshite, tsuini, futari wa, ki no ue de, mukaiaukotoga dekitanodatta.

Saat itu, kalau ada orang dewasa yang melihat Totto chan berdiri di cabang pohon dan menarik Yasuaki chan yang tengkurap dengan perut tertumpang 
pada tangga lipat pasti orang itu akan tidak biasa. Pemandangan itu pasti tampak berbahaya. Tapi, Yasuaki chan mempercayai Totto chan sepenuhnya. Dan, Totto chan memang sedang mempertaruhkan nyawa demi kawannya. Akhirnya, setelah lama berusaha, kedua anak itu berhadapan di lekuk cabang pohon.

Di sekolah yang baru, Totto chan bertemu dengan banyak teman baru. Temantemannya menurut Totto-chan memiliki keunikan masing-masing, salah satunya Yasuaki-chan yang memiliki gaya berjalan yang aneh. Ketika berjalan, tubuhnya bergoyang-goyang dan ia harus menyeret kakinya. Jari-jari tangan kiri Yasuaki-chan seperti tertekuk dan menempel satu sama lain, pada akhirnya Totto-chan tahu bahwa Yasuaki-chan terkena polio. Walaupun begitu, Totto-chan berusaha mewujudkan mimpi temannya itu untuk bisa menaiki suatu pohon yang ada di halaman sekolah. Ia meyakinkan dirinya sendiri untuk bisa sama-sama memanjat pohon bersama Yasuakichan. Kutipan "Soshite, totto chan wa, jibun no zenseimei wo, konotoki, kaketeita. Soshite,tsuini, futari wa, ki no ue de, mukaiaukotoga dekitanodatta" menunjukkan niat dan usaha yang keras yang dimiliki Totto chan sehingga Totto-chan yang kecil akhirnya bisa membawa seorang anak yang terkena polio berada di atas dahan pohon yang cukup tinggi. Kutipan di atas sesuai dengan Goleman mengenai unsur kecerdasan emosi yaitu niat, di mana niat merupakan hasrat dan kemampuan untuk berhasil dan untuk bertindak berdasarkan niat itu dengan tekun. Ini berkaitan dengan perasaan terampil, perasaan efektif.

\section{Kendali diri}

ただ、自分より小さい人や弱い人を押しのけることや、乱暴をするの は、恥ずかしいことだ、ということや、散らかって入るところを見た ら、自分で勝手に掃除をする、とか、人の迷惑になるることは、なる ベくしないように、というようなことが、毎日の生活の中で、いつの 間にか、体の中に入っていた。(Madogiwa noTotto Chan : 102)

Tada, jibun yori chiisai hito ya yowai hito wo oshinokeru koto ya, ranbou wo suru nowa, hazukashii kotoda, toiukotoya, chirakatteiru kotokoro wo mitara, jibun de katte ni souji wo suru, toka, hito no noiwaku ni naru koto wa, 
Noor Laili Faizah, Sri Oemiati, Kecerdasan Emosional Tokoh Totto Chan dalam Novel Madogiwa no Totto Chan Karya Tetsuko Kuroyanagi Menurut Teori Goleman: Sebuah Analisis Psikologi

narubekushinaiyouni, toiuyouna koto ga, mainichi no seikatsu no naka de, itsu no ma nika, karada no naka ni haitte ita.

Kehidupan sehari-hari di Tomoe telah mengajarkan bahwa tidak boleh mendorong orang yang lebih kecil atau lemah, bersikap tidak sopan berarti mempermalukan diri sendiri, dan tidak boleh membuat orang lain terganggu.

Tidak boleh mengganggu orang lain, tidak boleh menyakiti orang yang lemah dan bersikap sopan kepada orang lain, hal-hal tersebut mengajarkan Totto chan untuk dapat mengelola emosi terhadap diri sendiri dan orang lain. Kutipan di atas menurut Goleman berdasar unsur kecerdasan emosional yaitu kendali diri, di mana kendali diri merupakan kemampuan untuk menyesuaikan dan mengendalikan tindakan dengan pola yang sesuai dengan usia, suatu rasa kendali batiniah.

トットちゃんは、ひとりで泣きながら庭に穴を掘って、二羽を埋めた。 そして、小さいお花を、お供えした。(Madogiwa no Tottochan: 117)

Totto chan wa, hitori de naki nagara niwa ni ana wo hotte, niwa wo umeta. Soshite chiisai ohana wo, osonaeshita.

Sambil menangis, Totto chan menggali lubang di kebun lalu menguburkan dua unggas mungil itu kemudian meletakkan sekuntum bunga mungil di atasnya.

『じゃね』と、トットちゃんは、小さな声で、泰明ちゃんに、いった。 『いつか、うんと大きくなったら、また、どっかで、逢えるんでしょ う。そのとき、小児麻痺、なおってると、いいけど』。(Madogiwa no Totto chan : 240)

"jane" to Totto chan wa, chiisana koe de, Yasuaki chan ni, itta. "itsuka, unto ookikunattara, mata, dokkade, aerundeshou. Sonotoki, shounimahi, naoteruto, iikedo"

"Selamat jalan", bisiknya kepada Yasuaki chan. "Mungkin kita akan bertemu lagi entah di mana jika kita sudah tua. Mungkin waktu poliomu sudah sembuh".

トットちゃんは、部屋に入ると、泣きそうになるのを我慢し て、・・(Madogiwa no Totto chan : 258)

Totto chan wa, heya ni hairu to, nakisouni naru no wo gamanshite...

Ketika masuk kamar, totto chan berusaha tidak menangis atau memikirkanRokky. 
Ketiga kutipan tersebut menunjukkan saat anak ayamnya mati, Yasuaki chan temannya Totto chan yang mengidap polio meninggal dan Rocky-anjing gembala Jerman kesayangannya mati memberikan makna mendalam bagi Totto chan tentang menghadapi rasa kehilangan dan mengikhlaskannya. Sehingga Totto chan mampu mengelola emosinya dengan baik. Kutipan tersebut sesuai unsur kecerdasan emosional yaitu kendali diri, di mana kendali diri adalah kemampuan untuk menyesuaikan dan mengendalikan tindakan dengan pola yang sesuai dengan usia, suatu rasa kendali batiniah.

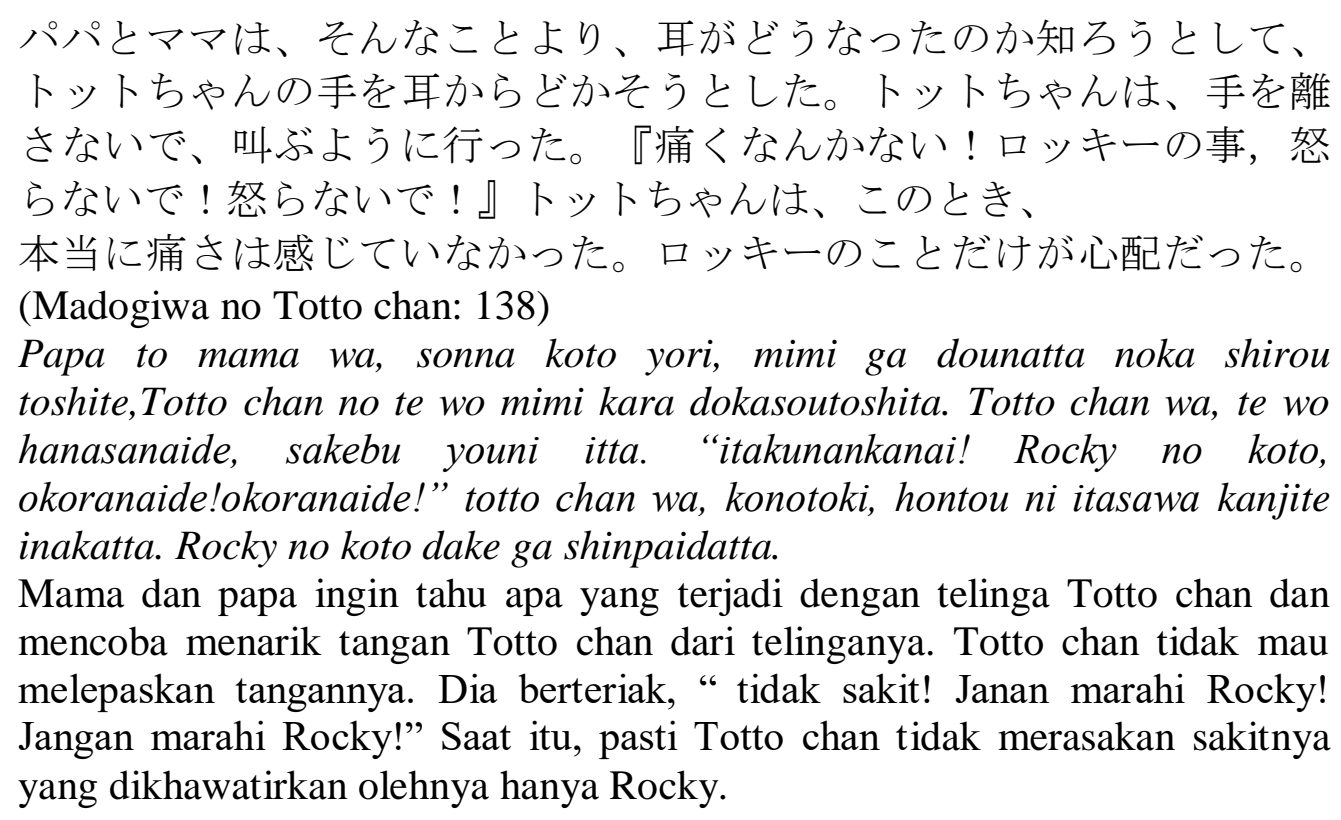
toshite,Totto chan no te wo mimi kara dokasoutoshita. Totto chan wa, te wo hanasanaide, sakebu youni itta. "itakunankanai! Rocky no koto, okoranaide!okoranaide!" totto chan wa, konotoki, hontou ni itasawa kanjite inakatta. Rocky no koto dake ga shinpaidatta.

Mama dan papa ingin tahu apa yang terjadi dengan telinga Totto chan dan mencoba menarik tangan Totto chan dari telinganya. Totto chan tidak mau melepaskan tangannya. Dia berteriak, " tidak sakit! Janan marahi Rocky! Jangan marahi Rocky!” Saat itu, pasti Totto chan tidak merasakan sakitnya yang dikhawatirkan olehnya hanya Rocky.

Totto chan sangat sayang terhadap binatang. Terlebih pada Rocky, anjing kesayangannya. Ketika bermain dengan Rocky, telinganya tidak sengaja digigit oleh Rocky. Kutipan " Totto chan wa, te wo hanasanaide, sakebu youni itta. “itakunankanai! Rocky no koto, okoranaide!okoranaide!” menunjukkan rasa sayangnya terhadap Rokky sehingga dia menutupi kesalahan Rocky dan melindungi anjing itu. Dia takut kalau mama dan papanya mengusir anjing kesayangannya itu. Meskipun Rocky sudah menggigitnya, tetapi dia tidak marah pada Rocky dan malah melindungi anjing kesayangannya itu. Totto chan mampu mengendalikan emosinya dengan tidak memarahi anjingnya itu. 
Noor Laili Faizah, Sri Oemiati, Kecerdasan Emosional Tokoh Totto Chan dalam Novel Madogiwa no Totto Chan Karya Tetsuko Kuroyanagi Menurut Teori Goleman: Sebuah Analisis Psikologi

Kutipan di atas menurut Goleman berdasar unsur kecerdasan emosional yaitu kendali diri, di mana kendali diri merupakan kemampuan untuk menyesuaikan dan mengendalikan tindakan dengan pola yang sesuai dengan usia, suatu rasa kendali batiniah.

『どうしよう?・・・・・』そのとき、『お金をひろったとき、すぐ 交番へ』、って、だれかがいったことを思いだした。『でも、電車の 中に交番は、ないじゃないの?』(Madogiwa no Totto chan : 151)

"Doushiyou?...." sonotoki, “ okane wo hirotta toki, sugu kouban"tte, dareka ga itta koto wo omoidashita. "Demo, densha no naka ni kouban wa, naijanai no?"

“apa yang harus aku lakukan?”Saat itu dia teringat seseorang pernah berkata, kalau menemukan uang segera serahkan kepada polisi. Tapi di kereta tidak ada polisi. Jadi bagaimana?

Saat itu Totto chan menemukan uang di dalam kereta. Dia teringat perkataan seseorang jika menemukan uang, serahkan ke polisi. Dia mampu mengendalikan perilakunya dan tidak menurutkan pada dorongan hatinya untuk memiliki uang tersebut.

Kutipan di atas menurut Goleman berdasar unsur kecerdasan emosional yaitu kendali diri, di mana kendali diri merupakan kemampuan untuk menyesuaikan dan mengendalikan tindakan dengan pola yang sesuai dengan usia, suatu rasa kendali batiniah.

『もう大栄君が、オーエス！といっても、泣かない』( Madogiwa no Totto chan: 168)

"Mou ooekun ga,oesu!toittemo, nakanai"

"Aku takkan menangis lagi meskipun Ooekun mengejekku"

Rambut Totto chan dikepang. Rambut kepangnya itu ditarik oleh temannya yang bernama Ooe. Totto chan menangis saat itu. Tetapi karena dia mampu mengelola emosinya dengan baik dia dapat mengendalikan diri dan berjanji tidak akan menangis lagi jika temannya mengganggu. 
Kutipan di atas menurut Goleman berdasar unsur kecerdasan emosional yaitu kendali diri, di mana kendali diri merupakan kemampuan untuk menyesuaikan dan mengendalikan tindakan dengan pola yang sesuai dengan usia, suatu rasa kendali batiniah.

そんな時、突然、学校の外から、大きな、『はやし歌』が聞こえた。 『トモエ学園、ボロ学校! 入ってみても、ボロ学校!』、『これは、 ひどい!』と、トットちやんが思った。(Madogiwa no Totto chan : 205) トットちゃんは、残念に思いながら、ブラブラ歩きながら、学校のほ うに、もどって来た。このとき、なんとなく、自分の口から歌が出た。 それは、こうだった。『トモエ学園、いい学校!』。(Madogiwa no Totto chan : 206)

Sonna toki, totsuzen gakkou no soto kara, ookina, "hayashi uta” ga kikoeta. " Tomoe gakuen, boro gakkou! Haitte mitemo, boro gakkou”, 'kore wa, hibii!"to, totto chan ga omotta. Totto chan wa, zannen ni omoinagara, burabura aruki nagara, gakkou no houni, modotte kita. Konotoki, nantonaku, jibun no kuchi kara uta ga deta. Sorewa, koudatta " tomoe gakuen, ii gakkou!"

Tiba-tiba dari luar sekolah terdengar nyanyian nyaring ,"Sekolah Tomoe sekolah tua dan usang","jahat sekali"pikir Totto chan. Totto chan berjalan balik ke sekolah sambil berjalan dia bernyanyi, "Sekolah Tomoe sekolah yang hebat!"

Totto chan marah ketika mengetahui sekolahnya diejek oleh anak-anak dari sekolah lain dengan lagu yang menghina sekolahnya. Dia berani membela sekolahnya. Dengan memakai lagu yang digunakan untuk mengejek sekolahnya, dia mengubah liriknya menjadi nyanyian yang sangat indah. Dan membela sekolahnya. Totto chan memiliki rasa kepedulian yang tinggi terhadap sekolahnya.

Kutipan di atas menurut Goleman berdasar unsur kecerdasan emosional yaitu kendali diri, di mana kendali diri merupakan kemampuan untuk menyesuaikan dan mengendalikan tindakan dengan pola yang sesuai dengan usia, suatu rasa kendali batiniah.

トットちゃんは、少しは残念だったけど、（校長先生が困ってるんだ もの、いいや) と、すぐきめたのだった。(Madogiwa no Tottochan : 211) 
Noor Laili Faizah, Sri Oemiati, Kecerdasan Emosional Tokoh Totto Chan dalam Novel Madogiwa no Totto Chan Karya Tetsuko Kuroyanagi Menurut Teori Goleman: Sebuah Analisis Psikologi

Totto chan wa, sukoshi wa zannen dattakedo, (kouchou sensei ga komatterunda mono, iiya) to, sugu kimeta no datta

Totto chan merasa kecewa,tapi kepala sekolah jadi repot jika dia terus memakai pita tersebut, maka ia setuju.

Saat Totto-chan mengenakan pita baru dan Miyo-chan, putri ketiga kepala sekolah merengek ingin memiliki pita yang sama tetapi tidak ada yang menjual serupa, maka Totto-chan mau mengalah untuk tidak mengenakannya ke sekolah. Kutipan "Totto chan wa, sukoshi wa zannen dattakedo, (kouchou sensei ga komatterunda mono, iiya) to, sugu kimeta no data" ia belajar tentang mengenali emosi diri sendiri dan memahami orang lain meskipun dia kecewa karena tidak bisa memakai pita itu.

Kutipan tersebut menurut Goleman berdasar unsur kecerdasan emosional yaitu kendali diri, di mana kendali diri merupakan kemampuan untuk menyesuaikan dan mengendalikan tindakan dengan pola yang sesuai dengan usia, suatu rasa kendali batiniah.

\section{Keterkaitan}

トットちゃんは、もう、すっかり、みんなと友達になっていて、前か ら、ずーっと一緒にいるような気になっていた。(Madogiwa no Totto chan: 56).

Totto chan wa, mou, sukkari, minna to tomodachi ni natteite, maekara, zutto isshouni iru younna ki ni natteita.

Totto chan sudah berkenalan dan berteman dengan semua anak, ia merasa sudah lama mengenal mereka.

Totto chan mudah bergaul dengan teman-temannya meskipun dia baru pindah sekolah di sekolah yang baru. Kutipan "Totto chan wa, mou, sukkari, minna to tomodachi ni natteite, maekara, zutto isshouni iru younna ki ni natteita" menunjukkan bahwa Totto chan mampu melibatkan diri dengan orang lain. 
Kutipan diatas menurut Goleman berdasar unsur kecerdasan emosional yaitu keterkaitan, di mana keterkaitan adalah kemampuan untuk melibatkan diri dengan orang lain berdasar pada perasaan saling memahami.

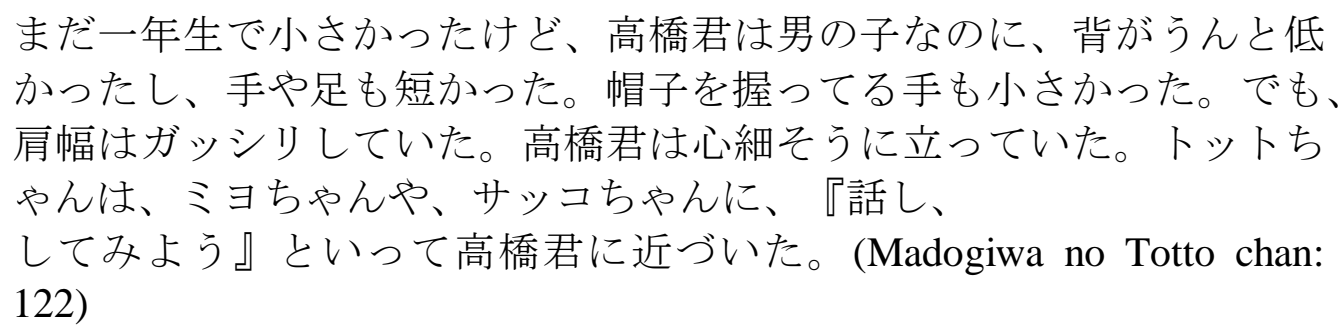

Mada ichinensei de chiisakattakedo, takahashi kun wa otoko no ko na noni, se ga unto hikukattashi, te ya ashi mo mijikatta. Boushi wo ninigitteru te mo chisakatta. Demo, haba wa gasshirishite ita. Takahashi kun wa kokoro hoso souni natte ita. Totto chan wa, miyo chan ya, sakko chan ni, "hanashi, shitemiyou"to itte takahashi kun ni chikazuita.

Totto chan masih kecil karena baru kelas satu, tetapi Takahashi, meskipun anak laki-laki tubuhnya jauh lebih kecil dari mereka. Lengan dan tungkai kakinya pendek. Tangannya yang memegangi topinya juga pendek. Tapi bahunya kekar. Takahashi berdiri dengan wajah muram. " Kita ajak dia bicara yuk ", kata Totto chan pada Miyo chan dan Sakko chan.

Kata-kata Totto chan wa, miyo chan ya, sakko chan ni, "hanashi, shitemiyou” to itte takahashi kun ni chikazuita menunjukkan bahwa Totto chan memiliki kemampuan untuk melibatkan diri dengan orang lain berdasarkan perasaan saling memahami. Meskipun temannya itu berbeda dengan dirinya tetapi dia ingin berteman dengannya. Hal tersebut sesuai dengan unsur kecerdasan emosional yaitu keterkaitan, di mana keterkaitan adalah kemampuan untuk melibatkan diri dengan orang lain berdasar pada perasaan saling memahami.

『私も、手でお話し、できたらいいのになあ』と、トットちやんは、 うらやましく思った。仲間に入ろうか、と思ったけど、どうやって、 手で、「私も入れて?」ってやるのかわからないし、トモエの生徒じ やないのに、お話したら失礼だと思って。(Madogiwa

no Totto chan : 156)

"watashi mo, te de ohanashi, dekitara ii noninaa" to, totto chan wa urayamashiku omotta. Nakama ni hairouka, toomottakedo, douyatte, te de "watashi mo irete?"tte yaru noka wakaranaishi, Tomoe no seito janai noni, ohanashitara shitsureidato omotte. 
Noor Laili Faizah, Sri Oemiati, Kecerdasan Emosional Tokoh Totto Chan dalam Novel Madogiwa no Totto Chan Karya Tetsuko Kuroyanagi Menurut Teori Goleman: Sebuah Analisis Psikologi

"Aku juga ingin bisa berbicara dengan menggunakan tangan" kata Totto chan dalam hati, dia ingin bergabung dengan mereka tapi tidak tahu bagaimana caranya bertanya pada mereka dengan menggunakan tangan. Lagipula, mereka bukan murid-murid Tomoe. Dia tidak mau berlaku tidak sopan.

Kutipan "watashi mo, te de ohanashi, dekitara ii noninaa" to, totto chan wa urayamashiku omotta menunjukkan bahwa Totto chan ingin dapat berbicara dan bergabung dengan anak-anak yang berkomunikasi menggunakan tangan. Hal ini merupakan kemampuan Totto chan untuk melibatkan diri dengan orang lain berdasarkan perasaan saling memahami. Kutipan diatas menurut Goleman berdasar unsur kecerdasan emosional yaitu keterkaitan, di mana keterkaitan merupakan kemampuan untuk melibatkan diri dengan orang lain berdasar pada perasaan saling memahami.

\section{Kecakapan Berkomunikasi}

。。。明日、学校に行くときもって行って、みんなの相談する。それ に、お金ひろった子なんていないんだから、『これが、ひろったお 金！』って見せてあげなきや。(Madogiwa no Totto chan:152)

...ashita, gakkou ni iku to kimotte okonatte, minna no soudsansuru. Soreni, okane hirotta ko nante inain dakara, " kore ga hirotta okane!" tte misete agenakya.

Besok akan aku bawa ke sekolah, aku akan minta pendapat temanteman. Akan kutunjukkan uang ini pada mereka, "aku menemukan uang jatuh".

"Aku akan meminta pendapat dari teman-teman", merupakan komunikasi dengan orang lain melalui tukar pikiran atau pendapat.

Kutipan di atas menurut Goleman berdasar unsur kecerdasan emosional adalah kecakapan berkomunikasi, di mana kecakapan berkomunikasi merupakan keyakinan dan kemampuan verbal untuk bertukar gagasan, perasaan, dan konsep dengan orang lain. Ini ada kaitannya dengan rasa percaya pada orang lain dan kenikmatan terlibat dengan orang lain, termasuk orang dewasa. 
トットちゃんは、ある日、勇気を出すと、その先生のそばに行った。 先生は男だけ、頭の毛の前髪を、おかっぱのように切っていて、毛も 少し，地じれていた。トットちゃんは、両手をおおきく広げ、白鳥の ように、ひらひらさせながら行った。『こういうの、 やんないの?』(Madogiwa no Totto chan: 186)

Totto chan wa, aru hi, yuuki wo dasuto, sono sensei no sobani itta. Sensei wa otoko dake, atama no ke no maegami wo, okappa no youni kitteite, ke mo sukoshi, chijireteita. Totto chan wa ryoute wo ookiku hiroge, shiratori no youni, hirahirasasenagara okonatta," kouiuno, yannaino?"

Pada suatu hari Totto chan mengumpulkan keberanian dan menghadap gurunya. Gurunya pria berambut ikal panjang dan dikepang. Totto chan merentangkan tangan dan menggerakkan keduanya seperti gerakan sepasang sayap angsa.

"Apakah kita tidak akan belajar menari seperti ini?"

Memiliki kepercayaan kepada orang lain diawali dari kepercayaan terhadap diri sendiri yang merupakan unsur kecerdasan emosi. Anak yang dapat mempercayai orang lain, menikmati kegiatan bersosialisasi dengan anak-anak lain dan orang dewasa., dalam hal ini kemampuan akan berbicara akan membantunya berkomunikasi dengan orang lain melalui tukar pikiran atau pendapat dan mengutarakan keinginan. ‘apakah kita tidak akan belajar seperti ini?’ merupakan keinginan yang diutarakan Totto chan pada gurunya.

Kutipan di atas menurut Goleman berdasar unsur kecerdasan emosional adalah kecakapan berkomunikasi, di mana kecakapan berkomunikasi merupakan keyakinan dan kemampuan verbal untuk bertukar gagasan, perasaan, dan konsep dengan orang lain. Ini ada kaitannya dengan rasa percaya pada orang lain dan kenikmatan terlibat dengan orang lain, termasuk orang dewasa.

トットちゃんは、自分で推薦して、お野菜を切る、「豚汁のかかり」 にいった。(Madogiwa no Totto chan: 195)

Totto chan wa, jibun de susenshite, oyasai wo kiru, "butajiro no kakari” ni itta.

Totto chan menawarkan diri mengiris sayuran dan bertanggung jawab atas sup daging babi. 
Noor Laili Faizah, Sri Oemiati, Kecerdasan Emosional Tokoh Totto Chan dalam Novel Madogiwa no Totto Chan Karya Tetsuko Kuroyanagi Menurut Teori Goleman: Sebuah Analisis Psikologi

Menikmati kegiatan bersosialisasi dengan anak-anak lain melalui tukar pendapat atau mengutarakan keinginan. Dalam hal ini, Totto chan menawarkan diri untuk memotong sayuran dalam sebuah kegiatan dengan teman-temannya.

Kutipan tersebut menurut Goleman berdasar unsur kecerdasan emosi yaitu kecakapan berkomunikasi, di mana kecakapan berkomunikasi merupakan keyakinan dan kemampuan verbal untuk bertukar gagasan, perasaan, dan konsep dengan orang lain. Ini ada kaitannya dengan rasa percaya pada orang lain dan kenikmatan terlibat dengan orang lain, termasuk orang dewasa.

\section{Kooperatif}

トットちゃんは、自分で推薦して、お野菜を切る、「豚汁のかかり」 にいった。(Madogiwa no Totto chan : 195)

Totto chan wa, jibun de susenshite, oyasai wo kiru, "butajiro no kakari" ni itta

Totto chan menawarkan diri mengiris sayuran dan bertanggung jawab atas sup daging babi.

Totto chan mampu melakukan kegiatan bersama-sama dengan anak lain. Dia mampu mnyeimbangkan kebutuhannya sendiri dengan kebutuhan orang lain dalam kegiatan berkelompok.

Kutipan tersebut menurut Goleman berdasar unsur kecerdasan emosi yaitu kooperatif, di mana kooperatif merupakan kemampuan untuk menyeimbangkan kebutuhannya sendiri dengan kebutuhan orang lain dalam kegiatan berkelompok.

\section{SIMPULAN}

Berdasarkan analisis data yang diteliti, penulis menemukan bahwa tokoh Totto chan memiliki kecerdasan emosional berupa keyakinan untuk berhasil sangat tinggi,selalu berusaha mencari tahu dan mencoba hal-hal baru, merencanakan dengan 
baik dan tidak berputus asa untuk mencapai tujuan ketika berniat melakukan sesuatu, memiliki kendali diri dalam menyesuaikan keinginannya dengan tuntutan lingkungannya, memiliki keterkaitan dengan keadaan orang lain yang sangat tinggi di mana tokoh utama mampu memahami situasi dan kondisi mereka, melakukan komunikasi dengan baik, mampu bersikap koperatif dengan orang lain.

Dari ketujuh pernyataan tersebut didapat bahwa kecerdasan emosi yang dimiliki tokoh Totto chan dalam menghadapi bagaimana caranya belajar tergolong tinggi karena memuat tujuh unsur kecerdasan emosional menurut teori Goleman. Adanya dukungan bagi Totto-chan dari orang-orang yang hebatlah yang membentuk kepribadian Totto chan menjadi anak yang dapat memahami dirinya sendiri dan orang lain. Walaupun di sekolah pertamanya ia dianggap pemberontak, susah diatur, nakal dan aneh, namun ia memiliki seorang ibu yang memiliki kesabaran dan rasa pengertian yang tinggi serta seorang Kepala Sekolah Sosaku Kobayashi yang luar biasa yang memiliki kedekatan emosional sangat tinggi dengan anak-anak, tiada batas dan percaya pada kemampuan mereka untuk menyelesaikan masalah mereka sendiri, sekolah Tomoe Gakuen yang membuat Totto-chan merasa nyaman dan tidak merasa dianggap aneh atau berbeda dari anak lainnya.

\section{REFERENSI}

-----(2002). Kamus Besar Bahasa Indonesia. Edisi Ketiga. Pusat Bahasa Departemen Pendidikan Nasional. Jakarta: Balai Pustaka

Amaryllia, P. (2009). Emotional Intelligent Parenting : Mengukur Emotional Intelligence dan Membentuk Pola Asuh Berdasarkan Emotional Intelligent Parenting. Jakarta: Gramedia

Aminuddin. (1990). Sekitar Masalah Sastra : Beberapa Prinsip dan Model Pengembangannya. Malang. Yayasan Asih Asah Asuh.

Bimo Walgito. (2004). Pengantar psikologi Umum. Yogyakarta: Andi.

Chandra, T. (2004). Kamus Indonesia Jepang. Cetakan Kesembilan. Jakarta: Evergreen Japanese Course.

Esthi Endah. (2008). Cerdas Emosional dengan Musik. Yogyakarta : Arti Bumi Intaran.

Goleman, D. (2007). Kecerdasan Emosional Mengapa EI lebih penting daripada IQ. Cetakan Ketujuh belas. Jakarta. Gramedia.

Hamzah B Uno. (2008). Orientasi Baru Dalam Psikologi Pembelajaran. Bumi Aksara. 
Noor Laili Faizah, Sri Oemiati, Kecerdasan Emosional Tokoh Totto Chan dalam

Novel Madogiwa no Totto Chan Karya Tetsuko Kuroyanagi Menurut Teori Goleman:

Sebuah Analisis Psikologi

Kuroyanagi, Tetsuko. (1981). Madogiwa no Totto chan. Japan: Kodansha International

M Atar Semi. (1993). Metode Penelitian Sastra. Angkasa.

Matsuura, Kenji. (1994). Kamus Bahasa Jepang-Indonesia. Japan: Kyoto Sangyo University Press.

Mubayidh, DR. Makmun. (2007). Kecerdasan dan Kesehatan Emosional Anak. Pustaka Al-Kautsar.

Ratna wulan. (2011). Mengasah Kecerdasan Pada Anak (bayi-pra sekolah). Yogyakarta: Pustaka Pelajar

Wellek, Rene dan Austin Warren. (1990). Teori Kesusastraan Terjemahan Melani Budianto. Jakarta. Gramedia.

Widya Kirana. (2004). Totto Chan : Gadis Cilik Di Jendela. Cetakan Kelima. Jakarta : PT Gramedia Pustaka Utama.

Unesaprodijepang.wordpress.com/2008/05/12/skripsi-bahasa-jepang-unesa/ 